NBER WORKING PAPER SERIES

DIFFERENCES IN INCOME ELASTICITIES AND TRENDS

IN REAL EXCHANGE RATES

\author{
Paul Krugman
}

Working Paper No. 2761

\author{
NATIONAL BUREAU OF ECONOMIC RESEARCH \\ 1050 Massachusetts Avenue \\ Cambridge, MA 02138 \\ November 1988
}

This research is part of NBER's research program in International studies. Any opinions expressed are those of the author not those of the National Bureau of Economic Research. 
NBER Working Paper \#2761

November 1988

\title{
DIFFERENCES IN INCOME ELASTICITIES AND TRENDS \\ IN REAL EXCHANGE RATES
}

\begin{abstract}
One might expect that differences in income elasticities in trade and/or differences in growth rates among countries would give rise to strong secular trends in real exchange rates; for example, fast-growing countries might need steady depreciation to get the world to accept their growing exports. In fact, however, income elasticities are systematically related to growth rates by the "45-degree rule", under which fast-growing countries appear to face high income elasticities of demand for their exports, while having low income elasticities of import demand. The net effect of this relationship between elasticities and growth rates is that secular trends in real exchange rates are much smaller than one might otherwise have expected: relative pPp holds fairly wel1. This paper documents the existence of a "45-degree rule", and suggests an explanation in terms of increasing returns and product differentiation.
\end{abstract}


What determines equilibrium real exchange rates? In the practical attempt to determine equilibrium rates, international economists generally exhibit a kind of schizophrenia. When we analyze short and medium run balance of payments developments, we use an income-and-price elasticity framework that presumes that the exports of different countries are imperfect substitutes for one another -- and indeed empirical implementation of this framework suggests fairly low price elasticities, implying that goods produced by different countries are not close substitutes. However, such a framework seems to imply that there should be substantial changes in equilibrium real rates over time, due either to differences in income elasticities or differences in growth rates. This is an implication that somehow we are unwilling to accept: when we do long run analysis we all seem to reveal a deep-seated belief in some form of purchasing power parity.

The purpose of this paper is twofold. First, I want to point out an empirical regularity; second, I want to argue that this empirical regularity lends support to a particular view of international trade that reconciles the seemingly contradictory views of many international economists about the short and long runs. 
The sicicis regularity is that the apparent income elasticities of demand for a country's imports and exports are systematically related to the country's long term rate of growth. Fast-growing countries seem to face a high income elasticity of demand for their exports, while having a low income elasticity of demand for imports. The converse is true for slow-growing countries. The result of this difference in income elasticities is, it turns out, just about sufficient to make trend changes in real exchange rates unnecessary. That is, although an income-and-price-elasticity framework in principle should give rise to substantial shifts in equilibrium real exchange rates over time, in practice the income elasticities turn out to be just right to make this unnecessary. I will refer to this empirical regularity as the "45-degree rule".

The theoretical point that follows from this is more questionable. I argue that the results on income elasticities are unlikely to be a coincidence. Instead, estimated income elasticities probably reflect a confounding of income effects with supply-side effects - a point that many authors have made. The new point here is that in order to explain the 45 -degree rule with its implication that there are not strong trends in real exchange 
rates, it is necessary to suppose that there is not much comparative advantage among industrial countries, and that their specialization at any point in time is largely arbitrary specialization due to increasing returns rather than comparative advantage trade.

The paper is in four parts. The first part considers the conventional income-and-price-elasticity analysis, and shows that this analvsis will normally imply substantial shifts in equilibrium real exchange rates over time. The second part reviews some historical estimates of income elasticities in world trade, and shows that these show a characteristic pattern of correlation with rates of growth, such that countries in general need much less real exchange rate movement over time than one would have expected a priori -- the 45-degree rule. The third part offers an explanation of this result that draws on the modern theory of trade based on increasing returns and imperfect competition. The fourth part then offers some updated results on income elasticities in the 1970s and 1980s, arguing that these new results support the general approach offered in this paper.

\section{The Significance of Income Elasticities}


A.thore much theoretical ifterature in international economics is set in a general equilibrium framework with fairly complex production structures and many relative prices, the workhorse of practical trade balance analysis is still, as it was a generation ago, the partial equilibrium analysis of trade flows that are assumed to depend on real income and a single relative price. This framework can be defended as a pretty close approximation to a more carefully specified framework in which expenditure as well as income enters into import demand; in any case, since this framework is still the way most practical analysis is done, it will be used as the starting point here without much apology.

Consider, then, a two-country world in which we define $y, y^{*}$ as domestic and foreign real output, $p, p^{*}$ as the prices in local currency of these outputs, and $e$ as the price of foreign currency in terms of domestic. Define $r=e^{*} / p$ as the real exchange rate, which is in this case the price of foreign relative to domestic goods. Then the standard trade balance model may be written as follows. Export volume depends on foreign output and the relative price of domestic goods: 


$$
x=x\left(y^{*}, r\right)
$$

Import volume depends on domestic income and the relative price of imports:

$$
\mathbf{m}=\mathbf{m}(\mathrm{y}, \mathrm{r})
$$

The trade balance (in domestic currency) may be written

$$
\begin{aligned}
B & =p x-e p^{\star} m \\
& =p[x-r m]
\end{aligned}
$$

so that the trade balance in terms of domestic output is simply

$$
b=x-r m
$$

Now it was pointed out in the 1950 s by Johnson (1958) that if the framework (1)-(4) is a reasonable description of trade balance determination, then economic growth is likely to require secular changes in real exchange rates. To see why, define the following. 
Let

$\zeta_{\mathrm{x}}=$ income elasticity of demand for exports

$\zeta_{\mathrm{m}}=$ income elasticity of demand for imports

$\epsilon_{x}=$ price elasticity of demand for exports

$\epsilon_{m}=$ price elasticity of demand for imports

$y=$ rate of growth of domestic output, $i, e,,(d y / d t) / y$

$\hat{y}^{*}=$ rate of growth of foreign output

$\hat{r}=$ rate of real depreciation

Now differentiate (4). We have

$$
d b / d t=x\left[\zeta_{x} \hat{y}^{*}+\epsilon \hat{x}\right]-\operatorname{rm}\left[\zeta_{m} \hat{y}+\left(I-\epsilon_{m}\right) \hat{r}\right]
$$

Suppose that initially $\mathrm{b}=0$, so that $\mathrm{x}=\mathrm{rm}$. Then in order to keep a zero trade balance, we must have

$$
\zeta_{\mathrm{x}} \hat{\mathrm{y}}^{\star}-\zeta_{\mathrm{m}} \hat{\mathrm{y}}+\left(\epsilon_{\mathrm{x}}+\epsilon_{\mathrm{m}}-1\right) \hat{\mathrm{x}}=0
$$

This implies a trend in the real exchange rate of 


$$
\hat{r}=\left[\zeta_{x^{y}} \hat{y}^{\star}-\zeta_{m} \hat{y}\right] /\left(\epsilon_{x}+\epsilon_{m}-1\right)
$$

Equation (7) immediately identifies two reasons why there may be a trend in the equilibrium exchange rate: either countries may face different elasticities of import and export demand, or they may have different long term rates of growth. More generally, we there will be a trend in the real exchange rate unless

$$
5_{x} / 5_{m}=\hat{y} / \hat{y}^{\star}
$$

which we would a priori imagine to be unlikely.

Suppose in particular that income elasticities are assigned to countries randomly, based on whatever happens to be their comparative advantage. Then (7) would lead us to expect rapidly growing countries to experience secular depreciation on average, needing progressively to cut the relative prices of their goods in order to be able to sell ever increasing volumes on world markets. Even without careful econometric analysis, it should immediately be clear to even casual observers that this assertion is not true. Japan has not experienced progressive real depreciation vis-a-vis the United States; if anything, the reverse 
has bers relationship of relative growth rates to relative income elasticities. Let us now turn briefly to some old econometric evidence to pin that relationship down.

2. The 45-degree Rule in the 1950 s and $1960 \mathrm{~s}$

In 1969 Houthakker and Magee published a paper that remains a benchmark for comparative estimation of trade equations across a large number of countries. Their main conclusion was that there were large differences among countries in their relative income elasticities -- specifically, that Japan faced the highly favorable combination of a high income elasticity of demand for its exports and a low income elasticity of import demand, while the US and the UK faced the reverse. While Houthakker and Magee did of course notice that Japan was the fastest growing country in their sample, while the US and the UK were the slowest, they did not explicitly consider the possibility that the differences in underlying growth rates were somehow systematically related to the differences in estimated income elasticities.

Yet it is difficult to escape this conclusion. Table 1 
presents the Houthakker-Magee income elasticity results for industrial countries, together with the growth rates of those countries over the period $1955-1965$. The relationship is striking; it becomes even more so when the ratio $5_{x} / 5_{m}$ is graphed against $y$, a plot shown in Figure 1.

Basically, what the Houthakker-Magee results show is that (8) holds -- that is, the ratio of income elasticities over their estimation period was such as to allow countries to have very different growth rates without strong trends in equilibrium real exchange rates. This may be confirmed more formally, by regressing the natural logarithm of the Houthakker-Magee elasticity ratio on the national growth rates ${ }^{1}$ :

$\begin{aligned} \ln \left(5_{x^{\prime}} / 5_{m}\right)=-1.81+ & 1.210 \ln \left(\hat{y} / \hat{y}^{*}\right) \\ & (0.208)\end{aligned}$

$\mathrm{R}^{2}=0.754, \mathrm{SEE}=0.211$

${ }^{1}$ Ideally we should use the ratio of domestic to foreign growth, but I was not able to reconstruct the "foreign" growth for the Houthakker-Magee sample. In the analysis of post-1970 data below the correct ratio is used. 
In this regersion we see that on average, if country A grew twice as rapidly as country $B$ over the period 1955-65, then country A turned out to have an estimated ratio of export to import elasticities that was twice that of country B.

The result of this systematic relationship between growth rates and income elasticities was to make relative purchasing power parity hold much better than one would have expected if one assumed that income elasticities were identical, or distributed randomly. One might have expected Japan to need to have rapidly falling relative export prices in order to accomodate its extremely rapid economic growth -- but the combination of high export elasticity and low import elasticity took care of that. One might have expected the UK to receive compensation for its low growth rate by a secular appreciation of its real exchange rate -. but the combination of low export elasticity and high import elasticity deprived it of that benefit.

Clearly something is going on here. It seems unlikely that the systematic association of growth rates and income elasticities is a pure coincidence. So our next step is to turn to potential explanations . 


\section{Explaining apparent income elasticity differences}

The close association between growth rates and the favorableness of income elasticities could have two types of explanation. On one side, income elasticities could determine growth: countries that happen to face unfavorable income elasticities could find themselves running into balance of payments problems whenever they try to expand. If this forces them into stop-go economic policies that inhibit growth, the result could be to limit growth to a level consistent with little real exchange rate change over time. The same result would occur if a wage-price spiral prevents effective real depreciation; then countries would not be able to achieve the real depreciation necessary to grow faster than the relative rate dictated by the income elasticities.

The other basic explanation is that differential growth rates affect trade flows in such a way as to create apparent differences in income elasticities. That is, we may conclude that there is a supply-side element in the apparent differences in demand that countries face.

I am simply going to dismiss a priori the argument that 
income adserities determine economic growth, rather than the other way around. It just seems fundamentally implausible that over stretches of decades balance of payments problems could be preventing long term growth, especially for relatively closed economies like the US in the 1950s and 1960s. Furthermore, we al1 know that differences in growth rates among countries are primarily determined by differences in the rate of growth of total factor productivity, not differences in the rate of growth of employment; it is hard to see what channel links balance of payments due to unfavorable income elasticities to total factor productivity growth.

Thus we are driven to a supply-side explanation of the income elasticities. It is important, however, to think about what kind of supply-side explanation is needed. Simply to posit a supply curve for exports for each country will not help: as a country grows, its supply curve will shift out, but this will simply move it down the demand curve, not shift the curve. Admittedly, if countries face upward-sloping supply curves for exports and imports there will be some bias in empirical estimates that ignore this; but this seems unlikely to explain the basic stylized fact that countries seem able to grow at different rates without the 
need for trend shifts in real exchange rates.

A more sophisticated view would draw on the traditional analysis of the effects of growth on the terms of trade, as developed by Johnson (1958) and Bhagwat1 (1958,1961). That literature points out that when countries are not specialized in trade - that is, when they produce import-competing as well as exported products - growth may have ambiguous effects on the terms of trade. Growth that is biased toward exports will indeed require a secular deterioration in the terms of trade, but growth that is biased toward imports may actually improve the growing country's terms of trade. The key question is the effect of growth on the demand for imports: if growth reduces the demand for imports at a given terms of trade, as will be the case for sufficiently import-biased growth, then a growing country's terms of trade will improve over time.

There may be something to this. In the 1950 s and 1960 s, the fast-growing country was Japan, while the slow growing countries were the US and the UK. Japan was clearly playing catch-up with the rest of the industrial world, which meant that it was becoming more similar to the its trading partners. Now suppose that initially Japan had a comparative advantage in labor-intensive 
goods sut comparative disadvantage in capital-intensive goods. As it became more similar to other industrial countries, it would become relatively better at producing capital-intensive goods, so that its growth would be biased toward the sectors in which it did not initially have a comparative advantage and away from those sectors in which it did. This is precisely import-biased growth, and could explain why Japan did not need declining terms of trade. Conversely, the US and the UK were being caught up to: the world was becoming more similar to them, which would other things equal tend to worsen their terms of trade ${ }^{2}$.

Although the argument that fast-growing countries were experiencing import-biased growth is appealing in many respects, however, I am doubtful about its relevance in explaining the data in Figure 1, for three reasons. First, it explains why the apparent income elasticities could be favorable for fast-growing countries, but not why they are favorable to almost precisely the extent needed to yield zero trend in the real exchange rate. ${ }^{2}$ A more elaborate formulation of how technological catch-up can progressively worsen the terms of trade of the country being caught up to is offered in Krugman (1985) which in turn draws heavily on Dornbusch, Fischer, and Samuelson (1977). 
Second, this story has an implication about the shares of trade in income. Suppose that an economy grows, while the rest of the world does not. If the growing economy is not to have a deterioration in its terms of trade, it must have no increase in its import demand. Hence the share of imports in national income must fall: the economy must become more closed over time. Admittedly this result can be softened by making ceteris not paribus, e.g. by imagining that global trade liberalization is taking place, and that there is also some growth in other countries. However, the fact that stable terms of trade were in fact consistent with growing trade relative to income cast doubt on the view that import-biased growth in catch-up countries could explain the real exchange rate developments (or more to the point, the lack of them) in the 1950s and 1960s.

The third reason for skepticism about the traditional trade and growth explanation is that it is a contingent one: the 45-degree rule could happen, but there is no particular reas on why it should. In particular, it should not be expected to be stable over time. As we will see, however, the 45-degree rule has on the whole been stable over time, persisting in the 1970s and 1980s despite a major shift in relative growth rates. Thus $I$ at least am 
inspired es iol for more unusual explanations.

In looking for a more fundamental explanation of the 45-degree rule,let me engage in a bit of professional self-psychoanalysis. Why do international economists mostly believe at a gut level that rough purchasing power parity should obtain among industrial countries over the long run? The answer, I would submit, is that it is because we believe that the industrial nations are basically all pretty much the same. Germany and the US can produce pretty much the same things, and produce them about equally well; so if costs and prices in either country were very far off those in the other for an extended period, all production would tend to move there. In the long run, then, we expect competition over the location of production to keep relative prices from moving too far apart.

But if Germany and the US are pretty much alike, why do they trade at all? The answer has to be some arbitrary specialization that is driven not by comparative advantage but by the inherent advantages of specialization itself, which is to say by increasing returns. Thus (not surprisingly) I would argue that the 45-degree rule is best explained by appealing to the new theory of trade in which similar countries trade because of increasing returns rather 
than comparative advantage.

The story runs as follows. Fast growing countries expand their share of world markets, not by reducing the relative prices of their goods, but by expanding the range of goods that they produce as their economies grow. What we measure as exports and imports are not really fixed sets of goods, but instead aggregates whose definitions change over time as more goods are added to the 1ist. What we call "Japanese exports" is a meaningful aggregate facing a downward-sloping demand curve at any point in time; but as the Japanese economy grows over time, the definition of that aggregate changes in such a way as to make the apparent demand curve shift outward. The result is to produce apparently favorable income elasticities that allow the country to expand its economy without the need for a secular real depreciation.

To make this point more concrete, let us consider a minimal formal model. No effort will be made at realism; instead, the purpose is simply to offer a suggestive example of how the 45-degree rule could arise out of an increasing returns model of international trade.

The model we consider is the "rock-bottom" model introduced in Krugman (1980), based on the Dixit-Stiglitz(1977) model of 
monopolists competition. We suppose that there are two countries, Home and Foreign, and that each can produce and consume any of an infinite number of product varieties. These product varieties all enter symetrically into consumption, with everyone sharing the instantaneous utility function ${ }^{3}$

$$
U=\left(\theta^{-1} \sum c_{i}^{\theta}\right\}^{1 / \theta} \quad 0<\theta<1
$$

We suppose that each country has only one factor of production, which we will call "labor" but which may be envisaged as an aggregate of resources; the key point is that we ignore any differences in relative factor endowments among countries or in factor intensities among goods that would give rise to comparative advantage. Instead, trade arises because of increasing returns, which enter the model through the assumption that the labor ${ }^{3} I$ ignore the question of how consumption is allocate intertemporally. For the sake of argument, suppose that there is no capital mobility and that we ignore investment. Then at each point in time people simply maximize their instantaneous utility subject to their current income. Adding investment and capital flows will complicate the picture a little, but not much. 
required to produce a good involves a fixed cost:

$$
l_{i}-\alpha+\beta x_{i} \quad \text { for all } i
$$

where $l_{i}$ is the quantity of resources used to produce any good with nonzero output, and $x_{i}$ is the output of the good.

For each country there is a full employment constraint:

$$
L=\sum_{i} 1_{i}
$$

As pointed out in the work of Dixit and Stiglitz, a closed economy with this utility and technology will have a monopolistically competitive equilibrium. Each good that is produced will be produced by only one firm, since a firm could always choose to start a new good that is equally profitable, and thus has no incentive to contest markets with other firms. The firm producing any particular good will face an elasticity of demand

$$
\phi-1 /(1-\theta)
$$


Giver tols elasticity of demand, each firm will charge a price that is a markup over the wage rate:

$$
\mathrm{P} / \mathrm{w}=\beta / \theta
$$

The zero-profit condition then determines the output and employment per product:

$$
\begin{aligned}
& \mathrm{x}(\mathrm{p} / \mathrm{w}-\beta)=\alpha \\
& >\quad \mathrm{x}=\alpha \theta / \beta(1-\theta)
\end{aligned}
$$

and

$$
I=\alpha /(I-\theta)
$$

It follows that the number of product varieties produced in a country is simply proportional to its labor force:

$$
\mathrm{n}=\mathrm{L}(I-\theta) / \alpha
$$

Next, consider trade between two such economies, with labor 
forces $L$ and $L^{*}$. If transport costs may be neglected, these trading economies simply constitute a world economy with labor force $L+L^{*}$; wage rates and the prices of representative goods will be equalized whatever the relative size of the economies. Trade will result from the desire of consumers in each country to diversify their purchases: with Home producing $n$ varieties and Foreign $n^{*}$, each consumer spends a fraction of his income $n /(n+$ $\left.n^{*}\right)=L /\left(L+L^{*}\right)$ on Home goods, a fraction $n^{*} /\left(n+n^{*}\right)=L^{*} /\left(L+L^{*}\right)$ on Foreign goods.

Now note that Home income deflated by the price of a representative product is

$$
y=w L / p=L \theta / \beta
$$

The volume of Home imports is therefore

$$
M=\left[n /\left(n+n^{*}\right)\right] y
$$

and the volume of Home exports, analogously, is

$$
x=\left[n^{*} /\left(n+n^{*}\right)\right] y^{*}
$$


Now consider what happens if the Home and foreign economies are growing over time. We may represent growth as increases in $L$ and $L^{*}$, recognizing that productivity gains can be represented as increases in the effective labor forces. Then we may immediately note that even if the labor forces grow at different rates, the prices of representative products in the two countries will still be equalized. That is, there will be no real exchange rate change. The reason is that the faster growing country will be able to increase its share of world expenditure by increasing the number of goods it produces faster than the other country, allowing it to sel1 more without a reduction in its relative price.

By differentiating (19) and (20), we find that

$$
\hat{X}=\hat{M}=\hat{y}\left[y^{*} /\left(y+y^{*}\right)\right]+\hat{y}^{*}\left[y /\left(y+y^{*}\right)\right]
$$

Now suppose a naive econometrician were to attempt to fit a conventional trade model to this data. She would find an apparent income elasticity of export demand equal to

$$
\zeta_{x}=\hat{x} / \hat{y}^{\star}-\left(\hat{y} / \hat{y}^{*}\right)\left[y^{\star} /\left(y+y^{\star}\right)\right]+y /\left(y+y^{\star}\right)
$$


and similarly an apparent income elasticity of import demand equal to

$$
S_{\mathrm{m}}=\hat{\mathrm{M}} / \hat{\mathrm{y}}=\mathrm{y}^{\star} /\left(\mathrm{y}+\mathrm{y}^{\star}\right)+\left(\hat{\mathrm{y}}^{\star} / \hat{\mathrm{y}}\right)\left[\mathrm{y} /\left(\mathrm{y}+\mathrm{y}^{\star}\right)\right]
$$

We note immediately from (22) and (23) that the higher the relative growth rate of Home, the higher will be the apparent income elasticity of demand for its exports (other things equal) and the lower the apparent income elasticity of demand for imports. This of course simply reflects the effects of changing numbers of products that we have already alluded to. Furthermore, the ratio of these apparent income elasticities will in fact precisely fulfill the 45-degree condition:

$$
\zeta_{x} / \zeta_{m}=\hat{y} / \hat{y}^{*}
$$

We see, then, that a simple model in which trade arises because of economies of specialization rather than comparative advantage in effect predicts that an econometrician will find the 45-degree rule. The fundamental logic is that if countries are 
basically alike, then the prices of their typical traded outputs should be the same, and apparent income elasticities will be such as to make continued price equality possible.

If the 45 -degree rule is really a reflection of something fundamental about trade flows rather than something contingent or: particular circumstances, we should expect to find that it holds over different time periods. In particular, we should find that if a country's relative growth rate changes, its apparent income elasticities should change as well, so as to preserve the 45-degree rule. Thus our next step must be to examine the validity of the 45-degree rule in the 1970s and 1980s.

4. The 45-degree Rule in the 1970s and 1930s

Tables 2 and 3 report the results of a set of standard export and import equations estimated for industrial countries on annual data for the period 1971-1986. The dependent variables are

$$
\begin{aligned}
& X=\text { manufactures exports in } 1982 \text { prices } \\
& M=\text { manufactures imports in } 1982 \text { prices }
\end{aligned}
$$


The explanatory variables are

$Y=$ GNP in constant prices

$\mathrm{Y}^{*}$ - foreign GNP in constant prices, caiculated as a geometric average of GNP in 14 industrial countries, weighted by their 1978 shares of the exporting country's exports

RXP = OECD index of relative export prices of manufactures

RMP = relative price of manufactures imports, calculated as ratio of manufactures import unit value to GNP deflator

All data is from OECD Economic Outlook. All equations were estimated in log-linear form; where severe serial correlation was evident, a correction was made.

By and large, these estimates look fairly decent; taken one at a time, they might suggest the need for more careful cleaning of data, addition of some extra variables, etc., but they would not discourage a researcher from using the income-and-price-elasticity framework. The major exception is the UK, whose import equation refuses to make sense; I have not beer able to resolve this puzzle, and will drop the UK from subsequent. discussion. 
What we may note, however, is that there is still, as in the Houthakker-Magee results, a systematic tendency for high-growth countries to face favorable income elasticities.Table 4 presents a sumary of estimated income elasticities, their ratios, and growth rates (calculated by fitting trens to domestic and foreign GNP). When these results are plotted in Figure 2, the result is less striking than for the Houthakker-Magee data in Figure 1 .. partly because the spread of growth rates is smaller -- but the upward-sloping relationship is still apparent. On average the 45-degree rule continues to hold, although with much less confidence:

$$
\begin{aligned}
& \ln \left(\zeta_{\mathrm{x}} / \zeta_{\mathrm{m}}\right)=-0.00+\underset{(0.609)}{1.029 \ln \left(\hat{\left.\mathrm{y} / \hat{\mathrm{y}}^{*}\right)}\right.} \\
& \mathrm{R}^{2}=0.322, \mathrm{SEE}=0.401
\end{aligned}
$$

Perhaps a more illuminating test is to look at the way in which estimates changed from the earlier period to the later period. In the 1950 s and 1960s, as Houthakker and Magee noted, Japan was the country with highly favorable income elasticities, while the US and the UK were the countries disfavored. In the 
1970 s and 1980s there was a general convergence of growth rates. European growth rates decline more than those of the US, so that the US grew almost as rapidly as its trading partners; Japan, though still fast growing, was not as far out of line as before. Tf the analysis above is right, we should expect to find a decline in Japan's $5_{x} / \zeta_{m}$ ratio and a rise in that of the US. And indeed we do find this: according to the estimates made here, Japan's ratio of elasticities, while still high, is lower in my estimates than in the Houthakker-Magee results, while the US actually is estimated to have a $\zeta_{\mathrm{x}} / \zeta_{\mathrm{m}}$ greater than one.

\section{Conclusions}

This paper has suggested that the surprising thing about long term trends in real exchange rates is their absence. That is, over the long run relative purchasing power parity for the manufactures outputs of industrial countries holds better than we would expect given the fairly low price elasticities usually estimated. The way that conventional econometrics justifies this is by finding that countries with high growth rates face high income elasticities of demand for their exports while having low 
income elasticities of import demand, with the result being that their faster growth is accommodated without a need for secular real depreciation. I have offered this as a stylized fact in the data, and christened it the "45-degree rule". Like most stylized facts, this needs a little squinting to see in the charts, but I would argue that there is enough evidence for a systematic association between apparent income elasticities and relative growth rates to be regarded as something that needs explaining.

The best explanation, I would argue, is that trade among industrial countries largely does not reflect country-specific comparative advantages, leading countries to face long-term downward-sloping demand for their unique products. Instead, countries specialize to take advantage of scale economies at different levels; as countries grow they can expand their range of outputs, and hence increase their share of world markets without the necessity of secular real depreciation.

It should be clear that this is only a preliminary study. Ideally we would like to go beyond the simple regressions and simple model presented here to develop a model that explicitly links the long run to the short and medium run dynamics in which the conventional income-and-price-elasticity framework remains a 
crucial tool. However, if the paper draws attention to what I believe is an important if fuzzy empirical regularity, it will have served its purpose. 
Table 1: Income elasticities and growth rates in the 1950 s and 60 s Country Income elasticity of: Ratio Growth rate,

Imports Exports $\quad \underline{1955-65}$

$\begin{array}{lllll}\text { UK } & 1.66 & 0.86 & 0.52 & 2.82 \\ \text { US } & 1.51 & 0.99 & 0.66 & 3.46 \\ \text { BEL } & 1.94 & 1.83 & 0.94 & 3.77 \\ \text { SWE } & 1.42 & 1.76 & 1.24 & 4.18 \\ \text { NOR } & 1.40 & 1.59 & 1.36 & 4.41 \\ \text { SWITZ } & 1.81 & 1.47 & 0.81 & 4.66 \\ \text { CAN } & 1.20 & 1.41 & 1.18 & 4.66 \\ \text { NETH } & 1.89 & 1.88 & 0.99 & 4.67 \\ \text { DEN } & 1.31 & 1.69 & 1.29 & 4.74 \\ \text { IT } & 2.19 & 2.95 & 1.35 & 5.40 \\ \text { FRA } & 1.66 & 1.53 & 0.92 & 5.62 \\ \text { GER } & 1.80 & 2.08 & 1.56 & 6.21 \\ \text { JAP } & 1.23 & 3.55 & 2.89 & 9.40\end{array}$

Source: Income elasticities from Houthakker and Magee (1969), growth rates from International Financial Statistics. 
Tab1e 2: Estimates of Export Equations, 1971-86

Country Coefficients on:

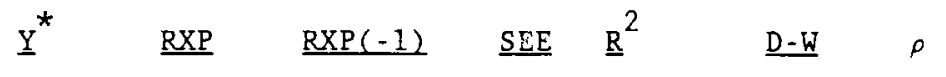

$\begin{array}{cccccccc}\text { Austria } & 3.05 & -0.56 & -0.04 & 0.03 & 0.992 & 2.11 & \ldots \\ & (0.10) & (0.42) & (0.42) & & & & \end{array}$

$\begin{array}{lccccccc}\text { Belgium } & 1.24 & 0.39 & -0.58 & 0.02 & 0.971 & 2.18 & \ldots \\ (0.13) & (0.16) & (0.14) & & & & \end{array}$

Canada $\begin{array}{ccccccc}2.87 & 0.62 & 0.18 & 0.02 & 0.996 & 1.96 & \ldots \\ & (0.09) & (0.20) & (0.18) & & & \end{array}$

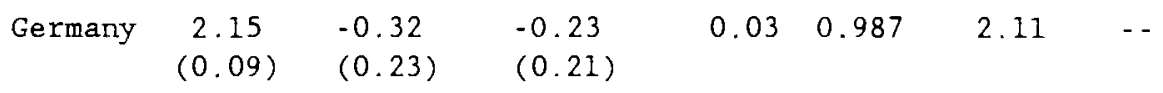

UK $\quad \begin{array}{ccccccc}1.30 & 0.00 & -0.54 & 0.03 & 0.963 & 2.01 & --\end{array}$

$\begin{array}{cccccccc}\text { Italy } & 2.41 & 0.08 & -0.31 & 0.04 & 0.982 & 1.61 & \cdots \\ & (0.11) & (0.19) & (0.20) & & & & \end{array}$

$\begin{array}{cccccccc}\text { Japiat } & 1.65 & -0.35 & -0.53 & 0.06 & 0.978 & 2.19 & 0.81 \\ & (0.80) & (0.18) & (0.21) & & & & \end{array}$

$\begin{array}{llllllll}\text { Neth } & 3.86 & -0.56 & -0.20 & 0.03 & 0.980 & 1.46 & 0.94\end{array}$ $(0.66) \quad(0.22) \quad(0.29)$

US

$\begin{array}{cccccc}1.70 & -0.44 & -0.98 & 0.04 & 0.976 & 2.10 \\ (0.08) & (0.16) & (0.16) & & & \end{array}$

A11 equations estimated on annual data, 1971-1986. Standard errors 


\section{Table 3: Estimates of Import Equations. 1971-86}

Country Coefficients on:

\begin{tabular}{|c|c|c|c|c|c|c|c|}
\hline & $\underline{Y}$ & $\underline{\mathrm{RMP}}$ & $\operatorname{RMP}(-1)$ & $\underline{\mathrm{SEE}}$ & $\underline{\mathrm{R}}^{2}$ & $\underline{D-W}$ & $\rho$ \\
\hline Austria & $\begin{array}{c}2.94 \\
(0.99)\end{array}$ & $\begin{array}{l}-0.14 \\
(0.43)\end{array}$ & $\begin{array}{c}0.41 \\
(0.75)\end{array}$ & 0.04 & 0.979 & 1.74 & 0.41 \\
\hline Be1gium & $\begin{array}{c}1.99 \\
(0.10)\end{array}$ & $\begin{array}{l}-0.39 \\
(0.16)\end{array}$ & $\begin{array}{c}0.14 \\
(0.15)\end{array}$ & 0.03 & 0.975 & 1.62 & -- \\
\hline Canada & $\begin{array}{c}1.66 \\
(0.27)\end{array}$ & $\begin{array}{l}-0.79 \\
(0.51)\end{array}$ & $\begin{array}{l}-0.66 \\
(0.51)\end{array}$ & 0.07 & 0.916 & 1.66 & 0.40 \\
\hline Germany & $\begin{array}{c}2.83 \\
(0.26)\end{array}$ & $\begin{array}{l}-0.33 \\
(0.20)\end{array}$ & $\begin{array}{c}0.24 \\
(0.26)\end{array}$ & 0.03 & 0.988 & 1.24 & 0.54 \\
\hline $\mathrm{UK}$ & $\begin{array}{l}-0.20 \\
(0.09)\end{array}$ & $\begin{array}{c}1.03 \\
(0.05)\end{array}$ & $\begin{array}{l}-0.04 \\
(0.04)\end{array}$ & 0.01 & 0.999 & 1.95 & 0.95 \\
\hline Italy & $\begin{array}{c}3.65 \\
(0.37)\end{array}$ & $\begin{array}{l}-0.51 \\
(0.20)\end{array}$ & $\begin{array}{l}-0.17 \\
(0.14)\end{array}$ & 0.04 & 0.981 & 1.69 & $\cdots$ \\
\hline Japan & $\begin{array}{c}0.80 \\
(1.19)\end{array}$ & $\begin{array}{c}0.03 \\
(0.29)\end{array}$ & $\begin{array}{l}-0.45 \\
(0.38)\end{array}$ & 0.12 & 0.928 & 1.51 & \\
\hline Neth & $\begin{array}{c}2.66 \\
(0.46)\end{array}$ & $\begin{array}{l}-0.11 \\
(0.14)\end{array}$ & $\begin{array}{l}-0.11 \\
(0.19)\end{array}$ & 0.02 & 0.987 & 2.13 & 0.79 \\
\hline US & $\begin{array}{c}1.31 \\
(0.44)\end{array}$ & $\begin{array}{c}0.11 \\
(0.34)\end{array}$ & $\begin{array}{l}-1.04 \\
(0.36)\end{array}$ & 0.08 & 0.957 & 1.62 & - \\
\hline
\end{tabular}

A11 equations estimated on annual data, 1971-86. Standard errors in parentheses. 
Table 4: Income Elasticities and Growth Rates, 197u

Country Growth rate of GNP:

Domestic Foreign Ratio
Income elasticity of:

Exports Imports Ratio

$\begin{array}{lllllll}\text { US } & 2.49 & 2.91 & 0.86 & 1.70 & 1.31 & 1.30 \\ \text { Neth } & 1.96 & 2.17 & 0.90 & 3.86 & 2.66 & 1.45 \\ \text { Germany } & 2.10 & 2.23 & 0.94 & 2.15 & 2.83 & 0.76 \\ \text { Belgium } & 2.15 & 2.19 & 0.98 & 1.24 & 1.99 & 0.62 \\ \text { Italy } & 2.56 & 2.37 & 1.08 & 2.41 & 3.65 & 0.66 \\ \text { Austria } & 2.63 & 2.08 & 1.26 & 3.06 & 2.60 & 1.18 \\ \text { Canada } & 3.59 & 2.55 & 1.41 & 2.87 & 1.66 & 1.73 \\ \text { Japan } & 4.15 & 2.37 & 1.75 & 1.65 & 0.80 & 2.06\end{array}$

Source: Tables 2 and 3 


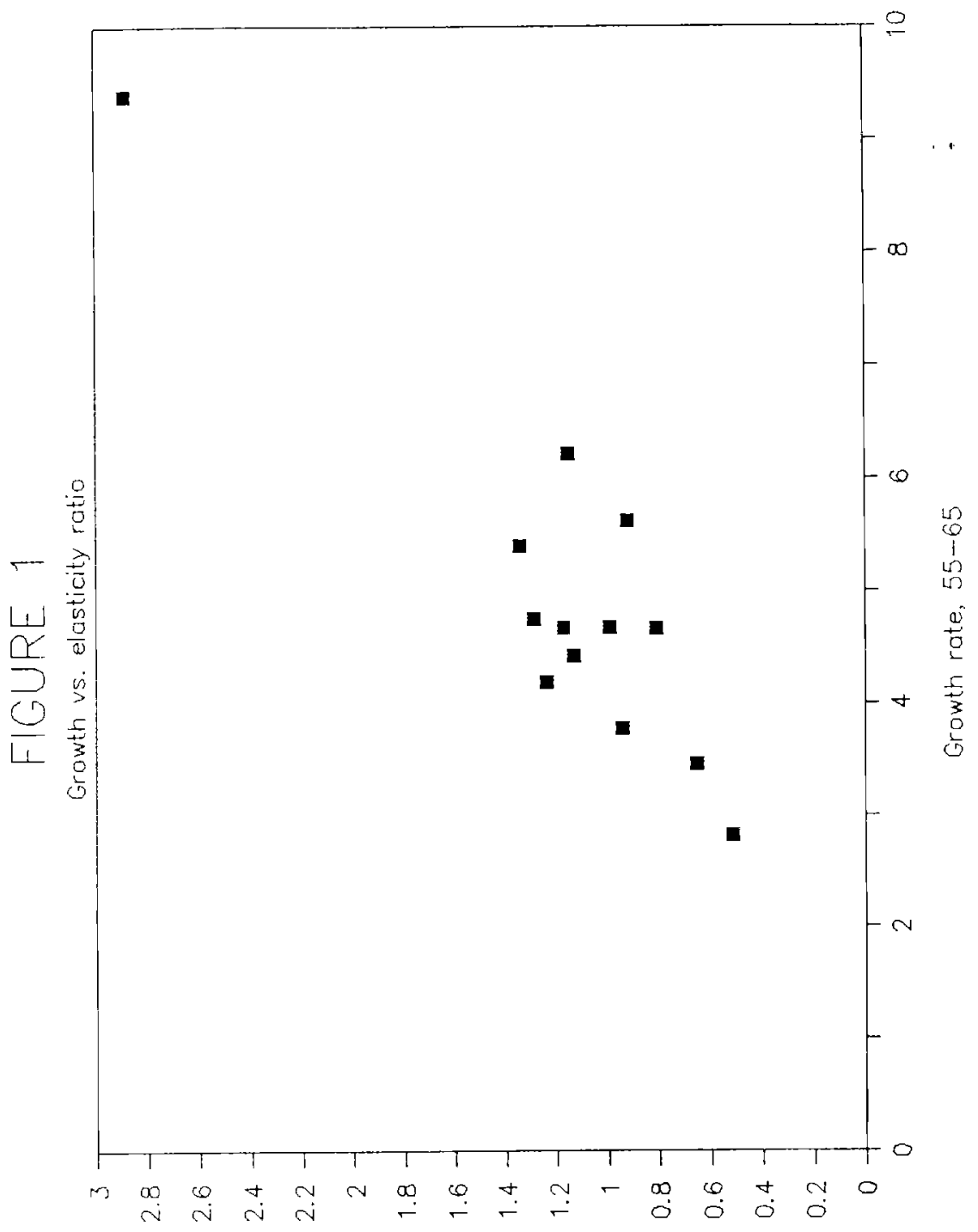

Kz!p!zsola quodul of 7aodxa jo o!foy 


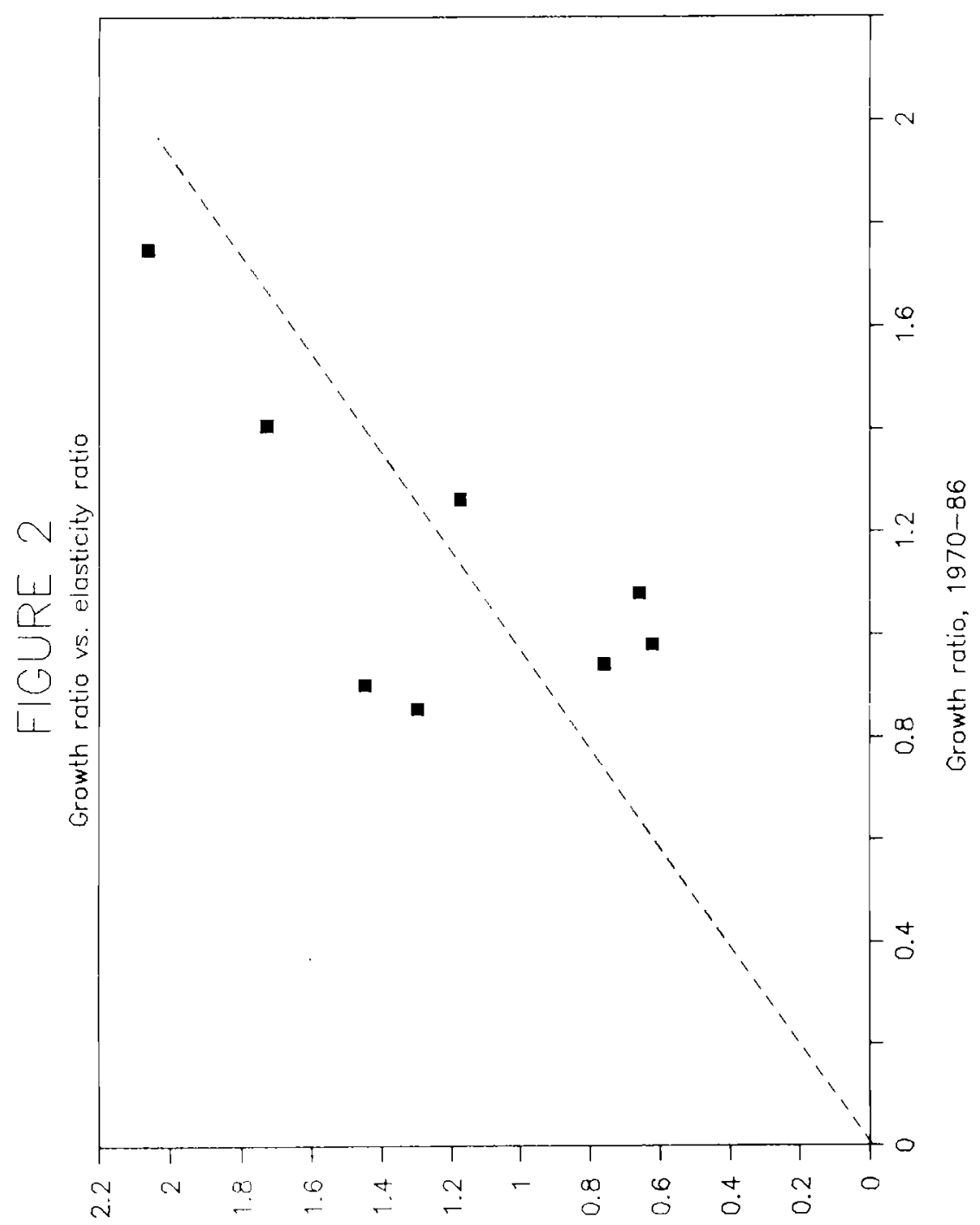

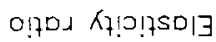




\section{REFERENCES}

Bhagwati,J. (1958): "Inmiserizing growth: a geometrical note", Review of Economic Studies 25, 201-205.

Bhagwati (1969): "International trade and economic expansion", in Trade. Tariffs, and Growth, Cambridge: MIT Press.

Dixit, A. and Stiglitz, J. (1977): "Monopolistic competition and equilibrium product diversity", American Economic Review 67 , $297-308$.

Goldstein,M. and Khan, M.(1985): "Income and price effects in foreign trade", in R. Jones and P. Kenen, eds., 花dbook of Internationa1 Economics II, Amsterdam: North-Ho1land.

Houthakker, H. and Magee, S. (1969): "Income and price elasticities in world trade", Review of Economics and Statistics, $51: 111-125$

Johnson, H. (1955): "Economic expansion and international trade", Manchester School of Economics and Social Studies, 23, 95-112.

Johnson, H. (1958): International Trade and Economic Growth: Studies in Pure Theory, London: Allen and Unwin. 
Krugman (1980): "Scale economies, product differentiation, and the pattern of trade", American Economic Review 70, 950-959. 